\title{
Reaction of Nitrilimines with
}

\section{2-Aminopicoline, 3-Amino-1,2,4-Triazole, 5-Aminotetrazole and 2-Aminopyrimidine}

\author{
Rami Y. Morjan1', Basam S. Qeshta', Hussein T. Al-Shayyah¹, John M. Gardiner²,

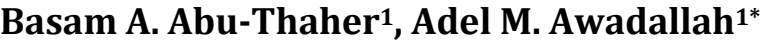 \\ ${ }^{1}$ Department of Chemistry, Islamic University of Gaza, Gaza, Palestine \\ ${ }^{2}$ Manchester Institute of Biotechnology, School of Chemistry and EPS, The University of Manchester, \\ Manchester, UK \\ Email: awada@iugaza.edu.ps
}

Received 3 July 2014; revised 22 August 2014; accepted 2 September 2014

Copyright (C) 2014 by authors and Scientific Research Publishing Inc.

This work is licensed under the Creative Commons Attribution International License (CC BY).

http://creativecommons.org/licenses/by/4.0/

cc) (i) Open Access

\begin{abstract}
The reaction of picoline derivatives 3-6 with hydrazonoylhalide 1a produced imidazo[1,2-a]pyridines 7-10, while the reaction of the same picoline derivatives with hydrazonoylhalide $1 \mathrm{~b}$ afforded imidazo[1,2-a]pyridine-2-ones 11-13. The reaction of $1 \mathrm{~b}$, c with 3-amino-1,2,4-triazole 14 produced the acyclic adducts 18 and 19, respectively. Reaction of 1b, 1c with 5-aminotetrazole 20 produced the acyclic products 23 and 24, respectively. Finally, the reaction of $1 \mathrm{~b}$ with 4 , 6-dimethyl-2-aminopyrimidine 27 afforded compound 29 rather than its isomeric structure 28. The structure of the products was confirmed by the different spectroscopic analytical methods including IR, MS, ${ }^{1} \mathrm{HNMR}$ and ${ }^{13} \mathrm{CNMR}$.
\end{abstract}

\section{Keywords}

Nitrilimines, Picolines, Imidazo[1,2-a]Pyridine, Triazoles, Tetrazoles, Pyrimidines

\section{Introduction}

Nitrilimines-generally generated in situ from hydrazonoyl halides are 1,3-dipolar species that are widely used for the synthesis of different heterocyclic systems via 1,3-dipolar cycloaddition reactions [1] [2], or cyclocondensation reactions [2]. Nitrilimines with C-acetyl or ester moiety represent a dielectrophilic system that may react with dinucleophilic heterocyclic systems at the carbonyl carbon of the acetyl or ester group, and at the terminal carbon of the dipole leading to fused heterocyclic systems. Recent examples include; the synthesis of im-

*Corresponding author.

How to cite this paper: Morjan, R.Y., Qeshta, B.S., Al-Shayyah, H.T., Gardiner, J.M., Abu-Thaher, B.A. and Awadallah, A.M. (2014) Reaction of Nitrilimines with 2-Aminopicoline, 3-Amino-1,2,4-Triazole, 5-Aminotetrazole and 2-Aminopyrimidine. International Journal of Organic Chemistry, 4, 201-207. http://dx.doi.org/10.4236/ijoc.2014.43023 
idazo[1,2-a]pyridines [3] [4] and their 2-one derivatives [4] from the reaction of nitrilimines with 2-amino-pyridine and imidazo[1,2-a]pyrazine from the reaction with 2-aminopyrazine [5]. Their reaction with 2-cyanomethylben-zimidazole gave pyrrolo[1,2-a]benzimidazole [6] [7]. The reaction of ethyl pyridine-2-acetate with nitrilimines having a C-acetyl moiety afforded the corresponding pyrrolo[1,2-a]pyridine, while their reaction with nitrilimines having a C-ester moiety afforded a cyclic adducts [8]. Similarly, the reaction of nitrilimines with a C-ester moiety with 2-cyanomethylbenzimidazole, and 2-amniobenzimidazole afforded a cyclic adducts [8]. In this work, we will investigate the reaction of nitrilimines with different amino heterocycles hoping to prepare new fused heterocyclic compounds that may be further tested for their biological activity. The following amino heterocycles will be used; aminopicolines, aminotriazole, aminotetrazole, aminoisoxazole and aminopyrimidine.

\section{Materials and Methods}

\subsection{Experimental}

${ }^{1} \mathrm{H}-\mathrm{NMR}$ spectra were recorded at 300 or $400 \mathrm{MHz}$ and ${ }^{13} \mathrm{C}-\mathrm{NMR}$ spectra at 75 or $100 \mathrm{MHz}$ on a Bruker AC300 or AC400 spectrometer. Chemical shifts are denoted in (ppm) relative to the internal solvent standard, TMS. ES-MS and HRMS were recorded on a Micromass LCT orthogonal acceleration time-of-flight mass spectrometer (positive and negative ion mode) with flow injection via a Waters 2790 separation module autosampler. FTIR spectra were recorded using Shimadzu 8201 spectrophotometer with $\mathrm{KBr}$ technique in region 4000 - 400 $\mathrm{cm}^{-1}$ that was calibrated by polystyrene. Melting point determinations were made using a Stuart Scientific SMP1 apparatus and are uncorrected. All chemicals and solvents were used without further purification, as supplied by Sigma-Aldrich unless otherwise stated. Hydrazonoylhalides 1a-c were prepared using Japp-Klingman method according to reported literature procedure [9].

\subsubsection{General Procedure for Syntheses of Compounds 7-10 and 11-13}

Triethylamine $(0.6 \mathrm{~g}, 0.006 \mathrm{~mol})$ in dry THF $(10 \mathrm{ml})$ was dropwise added to a stirred solution of hydrazonoyl chlorides 1a or $\mathbf{1 b}(0.005 \mathrm{~mol})$ and substituted picolines 3 - 6 (0.65 g, $0.006 \mathrm{~mol})$ in $25 \mathrm{ml}$ THF at room temperature producing imidazopyridines (7 - 10) and (11 - 13), respectively. Stirring was continued overnight, and the solvent was then evaporated in vacuo. The residual solid was washed with water to remove the triethylamonium salt, and the crude products were then recrystallized from the appropriate solvents to give the title compounds.

1) 3-[(4-Chlorophenyl)diazenyl]-2,8-dimethylimidazo[1,2-a]pyridine 7

Yield $93 \%$, Yellow solid, $\mathrm{mp} 152^{\circ} \mathrm{C}-155^{\circ} \mathrm{C}$; IR (KBr): $v_{\max } \mathrm{cm}^{-1}=1490,1416,1298,1282,1221,1200$, 1096, 811 and $774 \mathrm{~cm}^{-1}$. MS: $\mathrm{m} / \mathrm{z} \mathrm{C}_{15} \mathrm{H}_{13} \mathrm{ClN}_{4}\left(284 / 286 \mathrm{M}^{+}\right.$, chlorine isotope effect), HRMS (Calculated 284.0902, Found 284.0898). ${ }^{1} \mathrm{H}$ NMR (300 MHz, DMSO-d $\mathrm{d}_{6}$ ): $\delta 9.62$ (d, $\left.J=7.0 \mathrm{~Hz}, 1 \mathrm{H}\right), 7.89$ (d, $J=8.7 \mathrm{~Hz}$, 2H), $7.60(\mathrm{~d}, J=8.7 \mathrm{~Hz}, 2 \mathrm{H}), 7.51(\mathrm{~d}, J=7.0 \mathrm{~Hz}, 1 \mathrm{H}), 7.20(\mathrm{t}, J=7.0 \mathrm{~Hz}, 1 \mathrm{H}), 2.74\left(\mathrm{~s}, 3 \mathrm{H}, \mathrm{CH}_{3}\right), 2.58(\mathrm{~s}, 3 \mathrm{H}$, $\left.\mathrm{CH}_{3}\right) .{ }^{13} \mathrm{C}$ NMR (100 MHz, DMSO-d $\left.\mathrm{d}_{6}\right): \delta 166.2,151.4,138.2,136.1,135.4,131.2,129.0,127.3,124.0,123.0$, $119.2,15.2,10.3$

\section{2) 3-[(4-Chlorophenyl)diazenyl]-2,7-dimethylimidazo[1,2-a]pyridine 8}

Yield $78 \%$, Yellow solid, $\mathrm{mp} 174^{\circ} \mathrm{C}-177^{\circ} \mathrm{C}$; IR $(\mathrm{KBr}): v_{\max } \mathrm{cm}^{-1}=2993,1520,1473,1462$ and $796 \mathrm{~cm}^{-1}$; MS: $\mathrm{m} / \mathrm{z} \mathrm{C}_{15} \mathrm{H}_{13} \mathrm{ClN}_{4}$ (284/286 $\mathrm{M}^{+}$., chlorine isotopes effect); HRMS (284.0902, Found 284.0901); ${ }^{1} \mathrm{H}$ NMR (300 MHz, DMSO-d6): $\delta 9.66$ (d, $J=6.9 \mathrm{~Hz}, 1 \mathrm{H}), 7.88$ (d, $J=8.7 \mathrm{~Hz}, 2 \mathrm{H}), 7.59$ (d, $J=8.8 \mathrm{~Hz}, 2 \mathrm{H}+1 \mathrm{H}$ pyr.), 7.16 (d, $J=7.0 \mathrm{~Hz}, 1 \mathrm{H}), 2.71$ (s, 3H, $\left.\mathrm{CH}_{3}\right), 2.49$ (s, 3H, $\left.\mathrm{CH}_{3}\right) ;{ }^{13} \mathrm{C}$ NMR (100 MHz, DMSO-d6): $\delta 151,149,139$, 136, 131, 129, 129, 124, 121, 119, 111, 21, 10.

\section{3) 3-[(4-Chlorophenyl)diazenyl]-2,6-dimethylimidazo[1,2-a]pyridine 9}

Yield $94 \%$, green solid, mp. $145^{\circ} \mathrm{C}-147^{\circ} \mathrm{C}$; MS: $\mathrm{m} / \mathrm{z} \mathrm{C}_{15} \mathrm{H}_{13} \mathrm{ClN}_{4}\left(284 / 286 \mathrm{M}^{+}\right.$, chlorine isotopes effect); HRMS (Calculated 284.0902, Found 284.0897); ${ }^{1} \mathrm{H}$ NMR (300 MHz, DMSO-d ${ }_{6}$ ): $\delta 9.55$ (s, 1H), 7.91 (d, $J=8.7$ $\mathrm{Hz}, 2 \mathrm{H}), 7.67$ (d, $J=9.0 \mathrm{~Hz}, 1 \mathrm{H}), 7.60(\mathrm{~d}, J=8.7 \mathrm{~Hz}, 2 \mathrm{H}), 7.54$ (d, $J=9.0 \mathrm{~Hz}, 1 \mathrm{H}), 2.70\left(\mathrm{~s}, 3 \mathrm{H}, \mathrm{CH}_{3}\right), 2.43(\mathrm{~s}$, $\left.3 \mathrm{H}, \mathrm{CH}_{3}\right) ;{ }^{13} \mathrm{C}$ NMR $\left(100 \mathrm{MHz}\right.$ DMSO-d $\left.{ }_{6}\right):(\delta 161.0,151.0,138.0,136.0,131.0,130.0,129.0,126.0,124.0$, $119.0,111.0,17.0,10.0)$.

\section{4) 3-[(4-Chlorophenyl)diazenyl]-2,5-dimethylimidazo[1,2-a]pyridine 10}

Yield $93 \%$, orange solid, $\mathrm{mp} 157^{\circ} \mathrm{C}-159^{\circ} \mathrm{C}$; MS: $m / z \mathrm{C}_{15} \mathrm{H}_{13} \mathrm{ClN}_{4}\left(284 / 286 \mathrm{M}^{+}\right.$, chlorine isotopes effect); HRMS (Calculated 284.0902, Found 284.0908); ${ }^{1} \mathrm{H}$ NMR (300 MHz, DMSO-d $\left.\mathrm{d}_{6}\right): \delta 7.74(\mathrm{~d}, J=9.1 \mathrm{~Hz}, 2 \mathrm{H})$, 7.60 (d, $J=9.1 \mathrm{~Hz}, 2 \mathrm{H}), 7.45-7.60$ (m, 2H, overlapped), 7.12 (d, $J=6.8 \mathrm{~Hz}, 1 \mathrm{H}), 3.00$ (s, 3H, $\mathrm{CH}_{3}$ ), 2.71 (s, $\left.3 \mathrm{H}, \mathrm{CH}_{3}\right)$. 
5) 8-Methylimidzao[1,2-a]pyridine-2,3-dione-3-[4-chlorophenyl)hydrazone] 11

Yield, 30\%, Yellow solid, $\mathrm{mp}>300^{\circ} \mathrm{C}$; MS m/z $\mathrm{C}_{14} \mathrm{H}_{11} \mathrm{ClN}_{4} \mathrm{O}\left(286 / 288 \mathrm{M}^{+}\right.$, chlorine isotopes effect). HRMS (Calculated 286.0695, Found 286.0685). ${ }^{1} \mathrm{H}$ NMR (400 MHz, DMSO-d $\mathrm{d}_{6}$ ): $\delta 12.46$ (s, 1H, NH), 8.39 (d, $J=6.9$ $\mathrm{Hz}, 1 \mathrm{H}), 7.64(\mathrm{~d}, J=6.9 \mathrm{~Hz}, 1 \mathrm{H}), 7.60(\mathrm{~d}, J=6.9 \mathrm{~Hz}, 2 \mathrm{H}), 7.42(\mathrm{~d}, J=6.9 \mathrm{~Hz}, 2 \mathrm{H}), 6.88(\mathrm{t}, J=6.9 \mathrm{~Hz}, 1 \mathrm{H})$, $2.25\left(\mathrm{~s}, 3 \mathrm{H}, \mathrm{CH}_{3}\right)$.

6) 6-Methylimidzao[1,2-a]pyridine-2,3-dione-3-[4-chlorophenyl)hydrazone] 12

Yield 78\%, red solid, mp $96^{\circ} \mathrm{C}-98^{\circ} \mathrm{C}$; MS m/z $\mathrm{C}_{14} \mathrm{H}_{11} \mathrm{ClN}_{4} \mathrm{O}$ (286/288 $\mathrm{M}^{+}$, chlorine isotopes effect); HRMS (Calculated. 286.0695, Found 286.0700) ${ }^{1} \mathrm{H}$ NMR (400 MHz, DMSO-d $\mathrm{d}_{6}$ ): $\delta 15.55$ (s, $\left.1 \mathrm{H}, \mathrm{NH}\right), 8.23(\mathrm{~s}, 1 \mathrm{H})$, 7.66 (d, $J=8 . \mathrm{Hz}, 1 \mathrm{H}), 7.60$ (d, $J=8.4 \mathrm{~Hz}, 2 \mathrm{H}), 7.54$ (d, $J=8.4 \mathrm{~Hz}, 2 \mathrm{H}), 6.87$ (d, $J=8.4 \mathrm{~Hz}, 1 \mathrm{H}), 2.27$ (s, 3H, $\left.\mathrm{CH}_{3}\right) .{ }^{13} \mathrm{C}$ NMR (100 MHz, DMSO-d $\left.\mathrm{d}_{6}\right): \delta 202.0,150.0,149.0,140.0,136.0,133.0,131.0,130.0,127.0,112.0$, 111.0, 18.0.

7) 5-Methylimidzao[1,2-a]pyridine-2,3-dione-3-[4-chlorophenyl)hydrazone] 13

Yield $30 \%$, Yellow solid, $\mathrm{mp} 232^{\circ} \mathrm{C}-235^{\circ} \mathrm{C}$; MS $\mathrm{m} / \mathrm{z} \mathrm{C}_{14} \mathrm{H}_{11} \mathrm{ClN}_{4} \mathrm{O}\left(286 / 288 \mathrm{M}^{+}\right.$, chlorine isotopes effect); HRMS (Calculated 286.0695, Found 286.0698). ${ }^{1} \mathrm{H}$ NMR (300 MHz, DMSO-d 6 ): $\delta 13.17$ (s, 1H, NH), 7.76 (t, $J$ $=8.0 \mathrm{~Hz}, 1 \mathrm{H}$ ), 7.46 (br.s, 4H, not splitted), 7.08 (d, $J=8.0 \mathrm{~Hz}, 1 \mathrm{H}, \mathrm{Py}), 6.88$ (d, $J=8.0 \mathrm{~Hz}, 1 \mathrm{H}, \mathrm{Py}$ ), 2.82 (s, 3H, $\left.\mathrm{CH}_{3}\right)$.

\subsubsection{General Procedures for Syntheses of Compounds 18, 19, 23, 24 and 29}

Triethylamine (0.6 g, $0.006 \mathrm{~mol})$ in THF (30 ml) and methanol $(10 \mathrm{ml})$ was drop-wise added to a stirred solution of hydrazonoyl chloride $\mathbf{1 b}$ or $\mathbf{1 c}(0.006 \mathrm{~mol})$ and the appropriate azole $(0.005 \mathrm{~mol})$ at room temperature. Stirring was continued for 24 hours. The solvent was then removed and the solid precipitate was washed with water $50 \mathrm{ml}$ and then washed with cold ethanol. The crude solid product was collected, dried and crystallized from hot ethanol.

1) Methyl 2-(3-amino-4H-1,2,4-triazol-4-yl)-2-(2-(4-chlorophenyl)hydrazono)acetate 18

Yield 50\%, yellow solid, mp $255^{\circ} \mathrm{C}-257^{\circ} \mathrm{C}$; MS: $\mathrm{m} / \mathrm{z} \mathrm{C}{ }_{11} \mathrm{H}_{11} \mathrm{ClN}_{6} \mathrm{O}_{2}\left(294 / 295 \mathrm{M}^{+}\right.$, chlorine isotopes effect). ${ }^{1} \mathrm{H}$ NMR (300 MHz, DMSO-d ${ }_{6}$ ): $\delta 10.88$ (s, $1 \mathrm{H}, \mathrm{NH}$ ), 7.95 (s, $1 \mathrm{H}, \mathrm{N}=\mathrm{CHN}$, triazole ring), 7.35 (s, $4 \mathrm{H}$, aromatic ring), $5.95\left(\mathrm{~s}, 2 \mathrm{H}, \mathrm{NH}_{2}\right), 3.74\left(\mathrm{~s}, 3 \mathrm{H}, \mathrm{OCH}_{3}\right) .{ }^{13} \mathrm{C} \mathrm{NMR}(100 \mathrm{MHz}, \mathrm{DMSO}) \delta 161.5(\mathrm{C}=\mathrm{O}), 154.0(\mathrm{~N}=\mathrm{CN}$, triazol ring), 142.28 (C, aromatic ring), 138.76 ( $\mathrm{CH}, \mathrm{NN}=\mathrm{CHN}$, triazol ring), 129.32 (C, aromatic ring), 126.42 (s), $117.45\left(\mathrm{CH}\right.$, aromatic ring), $116.57\left(\mathrm{CH}\right.$, aromatic ring), $52.7\left(\mathrm{OCH}_{3}\right)$.

2) 1-(3-amino-4H-1,2,4-triazol-4-yl)-1-(2-(2,5-dimethylphenyl)hydrazono)propan-2-one19

Yield $40 \%$, brown solid, $\mathrm{mp} 194^{\circ} \mathrm{C}-196^{\circ} \mathrm{C}$; MS: $\mathrm{m} / \mathrm{z} \mathrm{C}_{13} \mathrm{H}_{16} \mathrm{~N}_{6} \mathrm{O}\left(272 \mathrm{M}^{+}\right)$HRMS (Calculated 272.1386, found 272.1275). ${ }^{1} \mathrm{H}$ NMR (300 MHz, DMSO): $\delta 9.76$ (s, $\left.1 \mathrm{H}, \mathrm{NH}\right), 7.89$ (d, $J=1.3 \mathrm{~Hz}, 1 \mathrm{H}, \mathrm{CCHC}$, aromatic ring), $7.27(\mathrm{~s}, 1 \mathrm{H}, \mathrm{N}=\mathrm{CHN}$, trizole ring), 7.06 (d, $J=7.5 \mathrm{~Hz}, 1 \mathrm{H}, \mathrm{CH}$, aromatic ring), $6.84(\mathrm{~d}, J=7.5 \mathrm{~Hz}, 1 \mathrm{H}$, $\mathrm{CH}$, aromatic ring), $5.92\left(\mathrm{~s}, 2 \mathrm{H}, \mathrm{NH}_{2}\right), 2.46\left(\mathrm{~s}, 3 \mathrm{H}, \mathrm{CH}_{3}\right), 2.30\left(\mathrm{~s}, 3 \mathrm{H}, \mathrm{CH}_{3}\right), 2.25\left(\mathrm{~s}, 3 \mathrm{H}, \mathrm{CH}_{3}\right) .{ }^{13} \mathrm{C}$ NMR $(100$ MHz, DMSO) $\delta 190.5(\mathrm{C}=\mathrm{O}), 153.3(\mathrm{~N}=\mathrm{CN}$, triazol ring), 140.3 (C, aromatic ring), $138.8(\mathrm{CH}, \mathrm{NN}=\mathrm{CHN}$, triazol ring), 135.8 (C, aromatic ring), 130.9 ( $\mathrm{CH}$, aromatic ring), 125.9 (aromatic ring), 124.5 ( $\mathrm{CH}$, aromatic ring), 123.1 (C, aromatic ring), $117.8\left(\mathrm{CH}\right.$, aromatic ring), $24.7\left(\mathrm{CH}_{3}\right), 20.8\left(\mathrm{CH}_{3}\right), 17.1\left(\mathrm{CH}_{3}\right)$.

3) Methyl 2-(5-amino-1H-tetrazol-1-yl)-2-(2-(4-chlorophenyl)hydrazono)acetate 23

Yield $30 \%$, Yellow solid, mp $180^{\circ} \mathrm{C}-182^{\circ} \mathrm{C}$; IR (KBr) $v_{\max } \mathrm{cm}^{-1}: 3214,3168,3111$ and $1748 . \mathrm{MS}: \mathrm{m} / \mathrm{z}$ $\mathrm{C}_{10} \mathrm{H}_{10} \mathrm{ClN}_{7} \mathrm{O}_{2}(296)[\mathrm{M}+\mathrm{H}]^{+} .{ }^{1} \mathrm{H}$ NMR (300 MHz, DMSO), $\delta$ ppm: 11.12 (s, $\left.1 \mathrm{H}, \mathrm{NH}\right), 7.43$ (d, $J=9.0 \mathrm{~Hz}, 2 \mathrm{H}$, aromatic ring), 7.37 (d, $J=9.0 \mathrm{~Hz}, 2 \mathrm{H}$, aromatic ring), $7.12\left(\mathrm{~s}, 2 \mathrm{H}, \mathrm{NH}_{2}\right), 3.79\left(\mathrm{~s}, 3 \mathrm{H}, \mathrm{OCH}_{3}\right) .{ }^{13} \mathrm{C}$ NMR $(100$ MHz, DMSO) $\delta 160.88(\mathrm{C}=\mathrm{O}), 156.5(\mathrm{C}=\mathrm{N}), 141.9,129.7,127.3,116.9,116.5$ (aromatic ring), $53.1\left(\mathrm{OCH}_{3}\right)$.

4) 1-(5-amino-1H-tetrazol-1-yl)-1-(2-(2,5-dimethylphenyl)hydrazono)propan-2-one 24

Yield 48\%, pale Yellow solid, $\mathrm{mp} 161^{\circ} \mathrm{C}-162^{\circ} \mathrm{C}$; IR (KBr): $v_{\max } \mathrm{cm}^{-1}=3327.56,2980.65,2360,1660 \mathrm{~cm}^{-1}$. MS: $\mathrm{m} / \mathrm{z} \mathrm{C}_{12} \mathrm{H}_{17} \mathrm{~N}_{7} \mathrm{O}$ (273). ${ }^{1} \mathrm{H}$ NMR (400 MHz, DMSO) $\delta 10.24$ (s, $1 \mathrm{H}, \mathrm{NH}$ ), 7.26 (s, $1 \mathrm{H}, \mathrm{CH}$, aromatic ring), 7.08 (d, $J=7.6 \mathrm{~Hz}, 1 \mathrm{H}, \mathrm{CH}$, aromatic ring), $6.92\left(\mathrm{~s}, 2 \mathrm{H}, \mathrm{NH}_{2}\right), 6.88$ (d, $J=7.7 \mathrm{~Hz}, 1 \mathrm{H}, \mathrm{CH}$, aromatic ring), 2.47 (s, 3H, $\left.\mathrm{CH}_{3}\right), 2.30$ (s, 3H, $\left.\mathrm{CH}_{3}\right), 2.25$ (s, 3H, $\left.\mathrm{CH}_{3}\right) .{ }^{13} \mathrm{C}$ NMR (100 MHz, DMSO) $\delta 189.3(\mathrm{C}=\mathrm{O}), 155.96$ (NC=N, tetrazol ring), 140.04 (C, aromatic ring), $135.91(\mathrm{~N}=\mathrm{CN}), 131.09(\mathrm{CH}$, aromatic ring), $125.12(\mathrm{CH}$, aromatic ring), 124.75 (C, aromatic ring), 123.82 (C, aromatic ring), $118.66\left(\mathrm{CH}\right.$, aromatic ring), $24.65\left(\mathrm{CH}_{3}\right), 20.70$ $\left(\mathrm{CH}_{3}\right), 17.25\left(\mathrm{CH}_{3}\right)$.

5) Methyl-2-[(4-chlorophenyl) hydrazono]-2-(2'-imino-4',6'-dimethylpyrimidin-1'-(2'H)-yl)acetate 29

Yield 52\%, brown solid, $\mathrm{mp} 130^{\circ} \mathrm{C}-132^{\circ} \mathrm{C}$ MS: $\mathrm{m} / \mathrm{z} \mathrm{C}_{15} \mathrm{H}_{16} \mathrm{ClN}_{5} \mathrm{O}_{2}\left(333 / 335 \mathrm{M}^{+}\right.$, chlorine isotopes effect). ${ }^{1} \mathrm{H}$ NMR (400 MHz, DMSO) $\delta 9.80$ (s, 1H), 8.04 (s, 1H), 7.73 (s, 1H), 7.70 (d, 2H), 7.59 (d, 2H), 3.86 (s, 3H), 2.27 
(s, 3H), 1.91 (s, 3H).

\section{Results and Discussion}

The reaction of picoline derivatives 3-6 with hydrazonoyl chloride 1a in THF in the presence of $\mathrm{Et}_{3} \mathrm{~N}$ as a base at room temperature produced imidazo[1,2-a]pyridine 7-10 in $85 \%$ - 90\% yield, while the reaction of hydrazonylchloride 1b with substituted picolines 3-6 under the same reaction conditions afforded the expected imidazo[1,2-a]pyridine-2-ones 11-13 in 30\% - 70\% yield (Scheme 1). The structure of the products was confirmed by the different spectroscopic analytical methods including IR, MS, ${ }^{1} \mathrm{HNMR}$ and ${ }^{13} \mathrm{CNMR}$.

The reaction of $\mathbf{1}$ with 3-amino-1,2,4-triazole $\mathbf{1 4}$ in refluxing ethanol was reported by Shawali et al. to give imidazo[1,2-b] triazole $\mathbf{1 5}$ in very low yield [10]. On the other hand, and under the same reaction conditions, Graf reported that the reaction of $\mathbf{1 4}$ with hydrazonylchloride $\mathbf{1}(\mathrm{X}=\mathrm{Ar})$ afforded the acyclic adducts $\mathbf{1 6}$ [11]. Treatment of $\mathbf{1 6}$ with refluxing AcOH/AcONa led to formation of the cyclic fused product $\mathbf{1 8}$ via loss of a molecule of $\mathrm{NH}_{3}$. The structure of $\mathbf{1 6}$ and $\mathbf{1 7}$ were determined by X-ray crystallography.

In this work, the reaction of hydrozonylchlorides $\mathbf{1 b}$, $\mathbf{c}$ with 3-amino-1,2,4-triazole $\mathbf{1 4}$ in the presence of $\mathrm{Et}_{3} \mathrm{~N}$ and THF at room temperature (Scheme 2) afforded the acyclic adducts $\mathbf{1 8}$ and $\mathbf{1 9}$, respectively. This as-

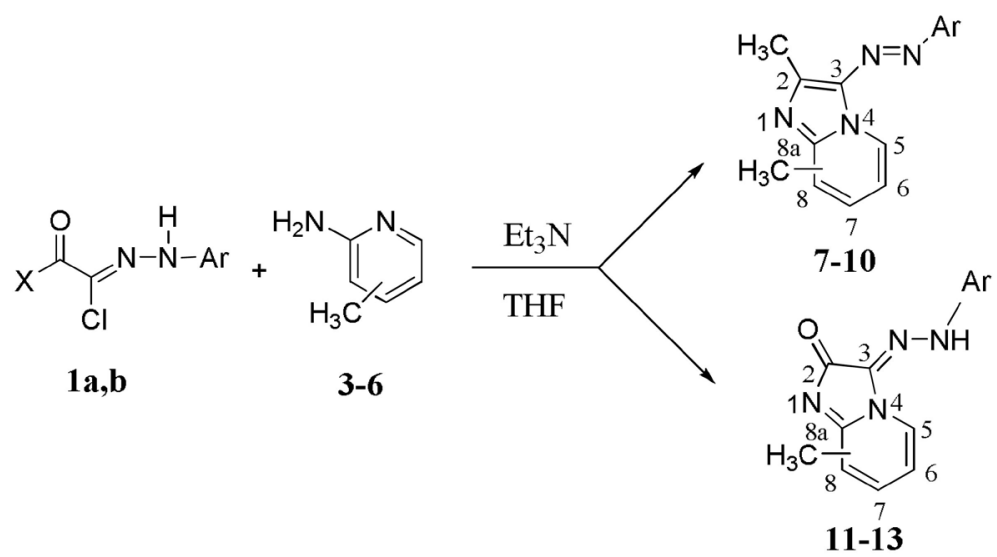

Scheme 1. Reaction of hydrazonylchloride 1a, b with substituted picoline 3-6.

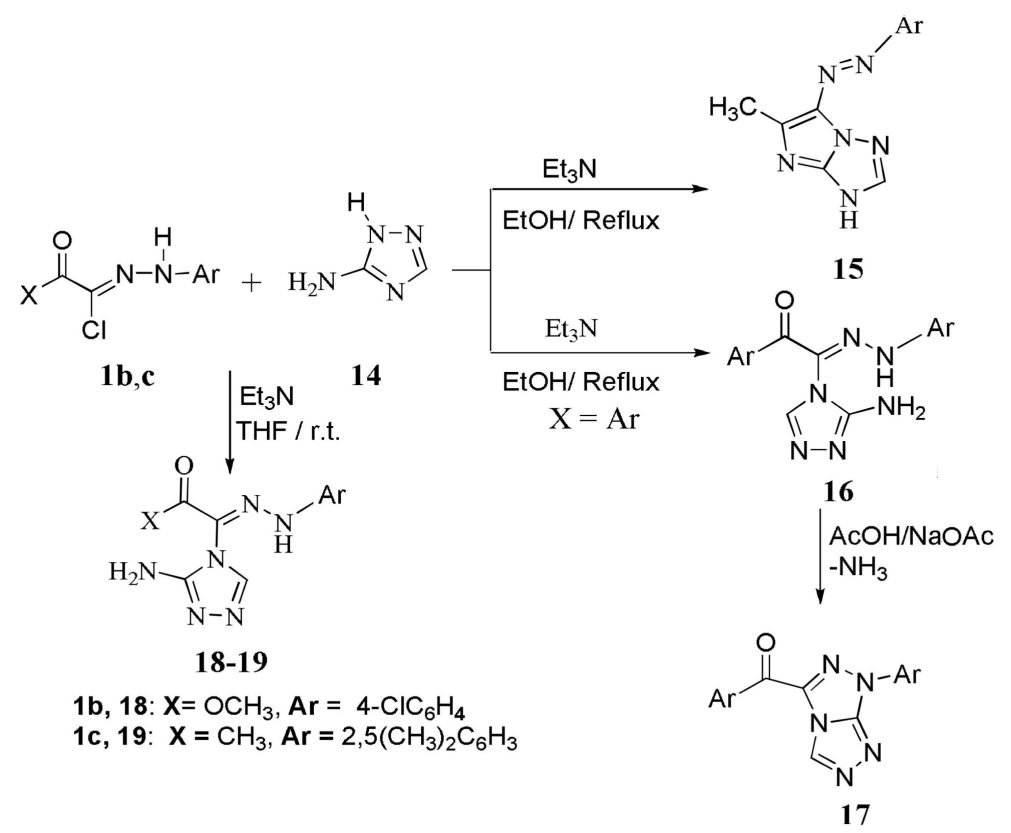

Scheme 2. Reaction of hydrazonylhalides 1b, c with 3-aminotriazole 14. 
signment is based on the appearance of the $\mathrm{NH}_{2}$ group and the $\mathrm{C}=\mathrm{O}$ group in both IR and NMR spectra. Similar to Graf product, the reaction is proposed to occur at the N4 of the triazole 14.The fused heterocyclic system reported by Shawali [10] was not obtained. Attempt to cyclize compounds 18 and 19 using AcOH/NaOAc (Graf method) was unsuccessful.

Graf reported [12] that the reaction of hydrazonylhalides $\mathbf{1}$ with 5-aminotetrazole $\mathbf{2 0}$ in refluxing ethanol produced compounds 22 via the rearrangement accompanied by loss of hydrazoic acid $\left(\mathrm{HN}_{3}\right)$ from the intermediate cycloaddition product 21. In this work; the reaction of hydrazonyl halides $\mathbf{1 b}$, 1c with 5-aminotetrazole 20 in THF in the presence of $\mathrm{Et}_{3} \mathrm{~N}$ at room temperature afforded the acyclic adducts $\mathbf{2 3}$ and 24, respectively (Scheme 3).

The reaction of hydrazonylhalide 1a with 2-aminopyrimidine $\mathbf{2 5}$ was reported by Awadallah et al. [8] to produce the pyrimido [2,1-d] 1,2,3,5-tetrazine $\mathbf{2 6}$. The reaction of $\mathbf{1 b}$ with 4, 6-dimethyl-2-aminopyrimidine $\mathbf{2 7}$ in THE in presence of $\mathrm{Et}_{3} \mathrm{~N}$ as a base at room temperature produced however, the acyclic adduct, 29. Two different possible isomeric structures are possible 28 and 29 (Scheme 4). The NMR data obtained provided an unambiguous confirmation that the actual obtained product is in fact compound $\mathbf{2 9}$ rather than compound $\mathbf{2 8}$. The assignment is based on the appearance of two $\mathrm{CH}_{3}$ groups at the pyrimidine ring. In compound $\mathbf{2 8}$ these two $\mathrm{CH}_{3}$ are identical as they are in the same chemical and electronic environment, so they should appear as one peak

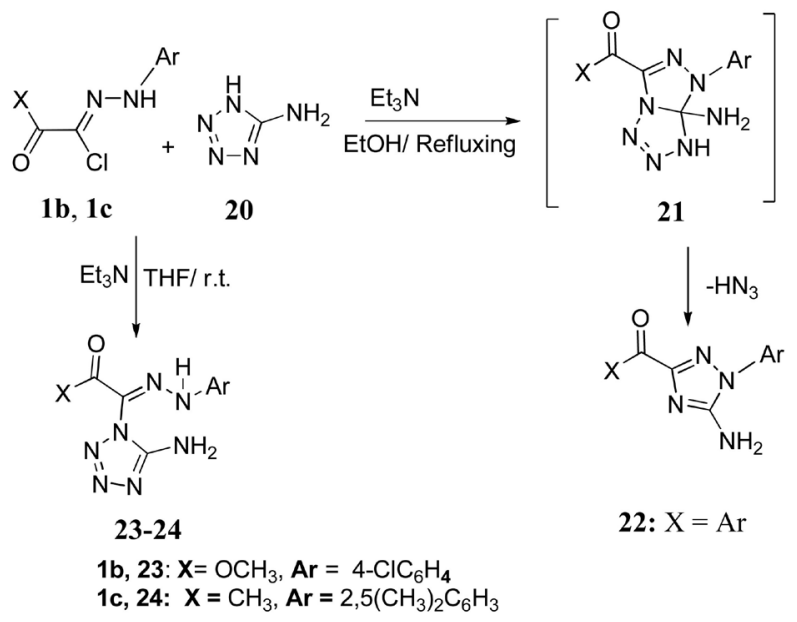

Scheme 3. Reaction of hydrazonylhalides $1 \mathrm{~b}, 1 \mathrm{c}$ with 5 -aminotetrazole 20.

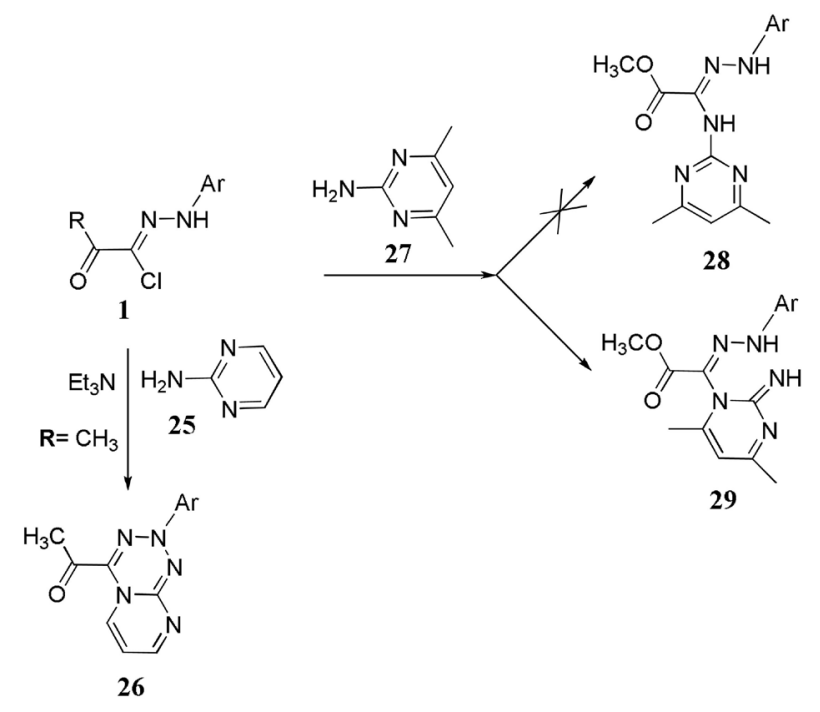

Scheme 4. Reaction of hydrazonylhalides 1 b with 4, 6-dimethyl 2-aminopyrimidin 27. 
with an integration value corresponding to $6 \mathrm{H}$. On the other hand, the two $\mathrm{CH}_{3}$ groups in compound 29 are different and two peaks with equal integration are expected. ${ }^{1} \mathrm{HNMR}$ spectra obtained supported structure $\mathbf{2 9}$ rather than $\mathbf{2 8}$. The mass spectra form compound 29 in both positive mode $234[\mathrm{M}+1]^{+}$and negative mode $232[\mathrm{M}-1]^{+}$ is shown in Figure 1.

\section{Conclusion}

A new series of heterocyclic compounds was synthesized via the reaction of Nitrilimines with 2-aminopicoline, 3-amino-1,2,4-triazole, 5-aminotetrazole and 2-aminopyrimidine. The structures of the products were characterized by IR, ${ }^{1} \mathrm{H}-\mathrm{NMR},{ }^{13} \mathrm{C}-\mathrm{NMR}$ and MS. The melting points of the synthesized compounds are listed in Table 1.

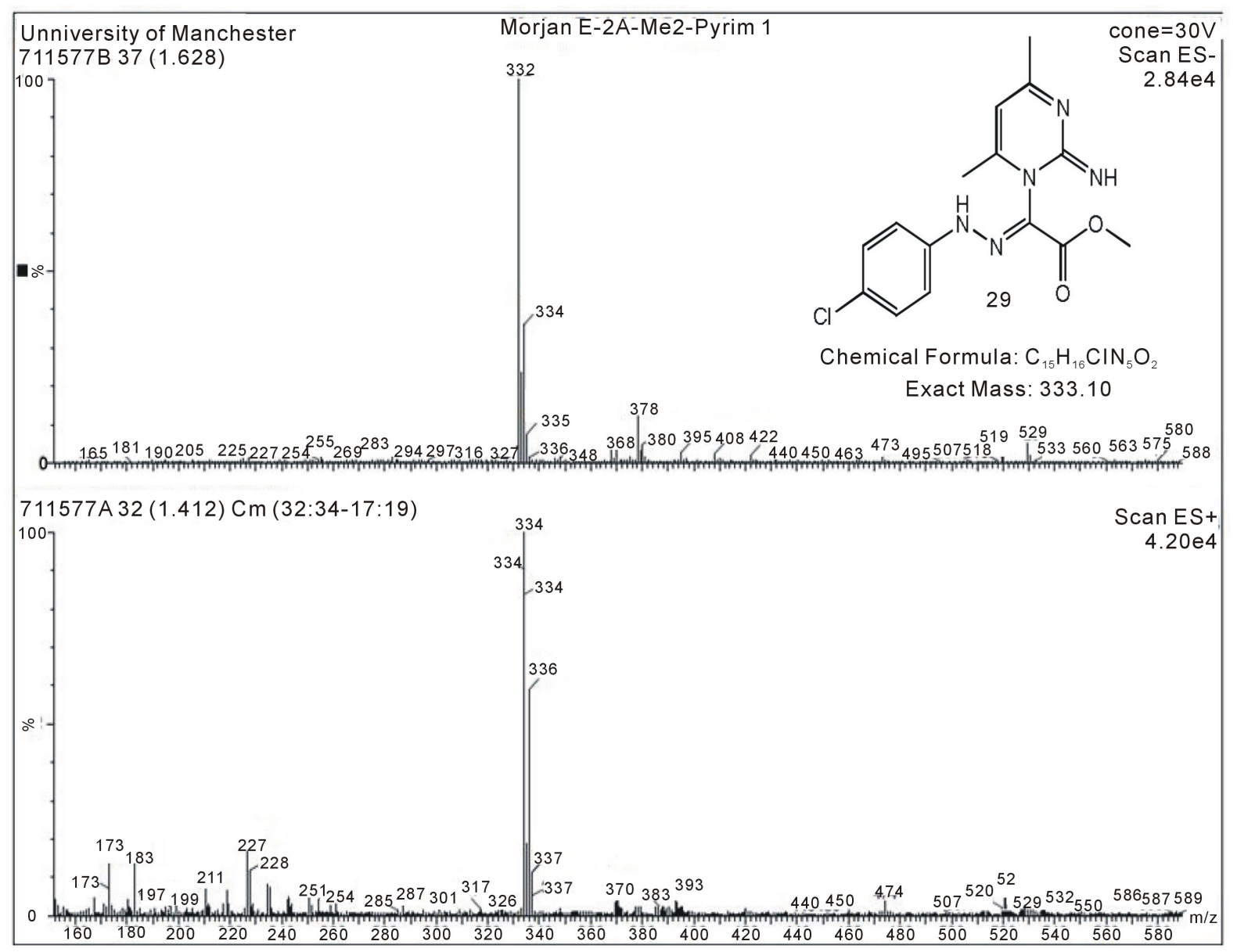

Figure 1. Mass spectra for compound 29 in both positive and negative mode.

Table 1. The melting points of the synthesized compounds.

\begin{tabular}{cccccccc}
\hline Comp. & M.F. & M.W & M.P. & Comp. & M.F. & M.W & M.P $^{\circ} \mathbf{C}$ \\
\hline $\mathbf{7}$ & $\mathrm{C}_{15} \mathrm{H}_{13} \mathrm{ClN}_{4}$ & 284 & $152-155$ & $\mathbf{1 3}$ & $\mathrm{C}_{14} \mathrm{H}_{11} \mathrm{ClN}_{4} \mathrm{O}$ & 286 & $232-235$ \\
$\mathbf{8}$ & $\mathrm{C}_{15} \mathrm{H}_{13} \mathrm{ClN}_{4}$ & 284 & $174-177$ & $\mathbf{1 8}$ & $\mathrm{C}_{11} \mathrm{H}_{11} \mathrm{ClN}_{6} \mathrm{O}_{2}$ & 294 & $255-257$ \\
$\mathbf{9}$ & $\mathrm{C}_{15} \mathrm{H}_{13} \mathrm{ClN}_{4}$ & 284 & $145-147$ & $\mathbf{1 9}$ & $\mathrm{C}_{13} \mathrm{H}_{16} \mathrm{~N}_{6} \mathrm{O}$ & 272 & $194-196$ \\
$\mathbf{1 0}$ & $\mathrm{C}_{15} \mathrm{H}_{13} \mathrm{ClN}_{4}$ & 284 & $157-159$ & $\mathbf{2 3}$ & $\mathrm{C}_{10} \mathrm{H}_{10} \mathrm{ClN}_{7} \mathrm{O}_{2}$ & 295 & $180-182$ \\
$\mathbf{1 1}$ & $\mathrm{C}_{14} \mathrm{H}_{11} \mathrm{ClN}_{4} \mathrm{O}$ & 286 & $>300$ & $\mathbf{2 4}$ & $\mathrm{C}_{12} \mathrm{H}_{17} \mathrm{~N}_{7} \mathrm{O}$ & 273 & $161-162$ \\
$\mathbf{1 2}$ & $\mathrm{C}_{14} \mathrm{H}_{11} \mathrm{ClN}_{4} \mathrm{O}$ & 286 & $96-98$ & $\mathbf{2 9}$ & $\mathrm{C}_{15} \mathrm{H}_{16} \mathrm{ClN}_{5} \mathrm{O}_{2}$ & 333 & $130-132$ \\
\hline
\end{tabular}




\section{Acknowledgements}

The authors would like to thank the Deanship of Scientific Research at the Islamic University of Gaza for their financial support. Thanks are due to Dr. Adeeb-El-Dhashan for his scientific contribution and help in spectroscopic analyses.

\section{References}

[1] Padwa, A. (1984) 1,3-Diploar Cycloaddition Chemistry. Wiley, New York.

[2] Ferwanah, A.R.S. and Awadallah, A.M. (2005) Reaction of Nitrilimines and Nitrile Oxides with Hydrazines, Hydrazones and Oximes. Molecules, 10, 492-507. http://dx.doi.org/10.3390/10020492

[3] Thaher, B. (2003) Synthesis and Characterization of Some New Substituted Imidazo[1,2-a]Pyridines. Abhath Al-Yarmouk Journal (Series of Natural Studies), 12, 555-561.

[4] Thaher, B. (2005) Synthesis of Some New Substituted Imidazo(1,2-a)Pyrazines. The Islamic University Journal (Series of Natural Studies and Engineering), 13, 109-115.

[5] Thaher, B. (2006) Synthesis of Some New Substituted Imidazo(1,2-a)Pyridines and Their 2-One Derivatives. The Islamic University Journal (Series of Natural Studies and Engineering), 14, 31-38.

[6] Awadallah, A.M., Seppelt, K. and Shorafa, H. (2006) Synthesis and X-Ray Crystal Structure of Pyrrolo[1,2-a]Benzimidazoles. Tetrahedron, 62, 7744-7746. http://dx.doi.org/10.1016/j.tet.2006.05.071

[7] Elwan N. (2004) A Facile Synthesis of Pyrrolo[1,2-a]Benzimidazoles and Pyrazolo[3,4:4,3’]Pyrrolo[1,2-a]Benzimidazole Derivatives. Tetrahedron, 60, 1161-1166. http://dx.doi.org/10.1016/j.tet.2003.11.068

[8] Awadallah, A.M. and Zahra J. (2008). Reaction of Nitrilimines with 2-Substituted Aza-Heterocycles. Synthesis of Pyrrolo[1,2-a]Pyridine and Pyrimido[2,1-d]1,2,3,5-Tetrazine. Molecules, 13, 170-176. http://dx.doi.org/10.3390/molecules13010170

[9] El-Abadelah, M.M., Hussein A.Q. and Thaher, B. (1991) Heterocycles from Nitrile Imines. Part IV. Chiral 4,5-Dihydro1,2,4-Triazin-6-Ones. Heterocycles, 32, 1879-1895. http://dx.doi.org/10.3987/COM-90-5637

[10] Shawali, A.S. (1993) Reactions of Heterocyclic Compounds with Nitrilimines and Their Precursors. Chemical Reviews, 93, 2731-2777. http://dx.doi.org/10.1021/cr00024a007

[11] Abdelhamid, A.O., Hassaneen, H.M., Shawaki, A.S. and Pārkānyāị, C. (1983) Reactions of $\alpha$-Ketohydrazidoyl Halides with Some Heterocyclic Amines. Facile Synthesis of Arylazo Derivatives of Fused Heterocycles with a Bridgehead Nitrogen Atom. Journal of Heterocyclic Chemistry, 20, 639-643. http://dx.doi.org/10.1002/jhet.5570200326

[12] Graf, H. and Klebe, G. (2006) 3-Aroyl-1-Aryl-1H-[1,2,4]Triazolo[3,4-c]-1,2,4-Triazole, Untersuchung des Bildungswegs durch Röntgenstrukturanalyse und Molecular Modelling. Chemische Berichte, 120, 965-977. http://dx.doi.org/10.1002/cber.19871200614 
Scientific Research Publishing (SCIRP) is one of the largest Open Access journal publishers. It is currently publishing more than 200 open access, online, peer-reviewed journals covering a wide range of academic disciplines. SCIRP serves the worldwide academic communities and contributes to the progress and application of science with its publication.

Other selected journals from SCIRP are listed as below. Submit your manuscript to us via either submit@scirp.org or Online Submission Portal.
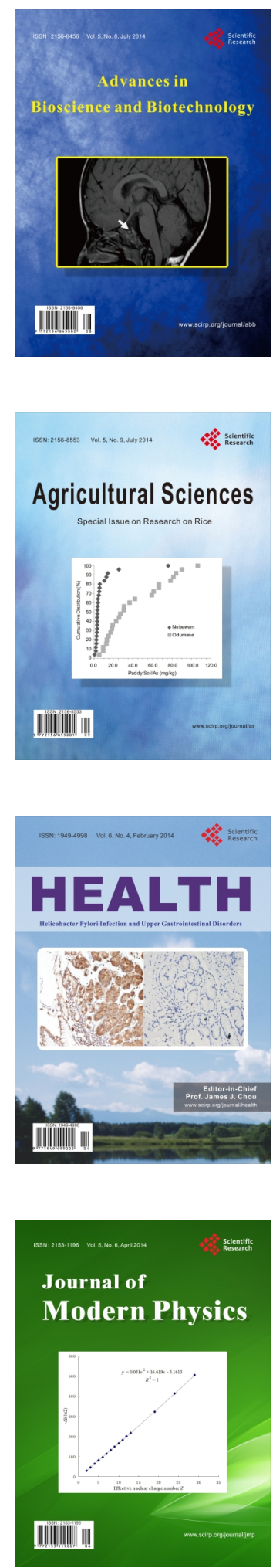
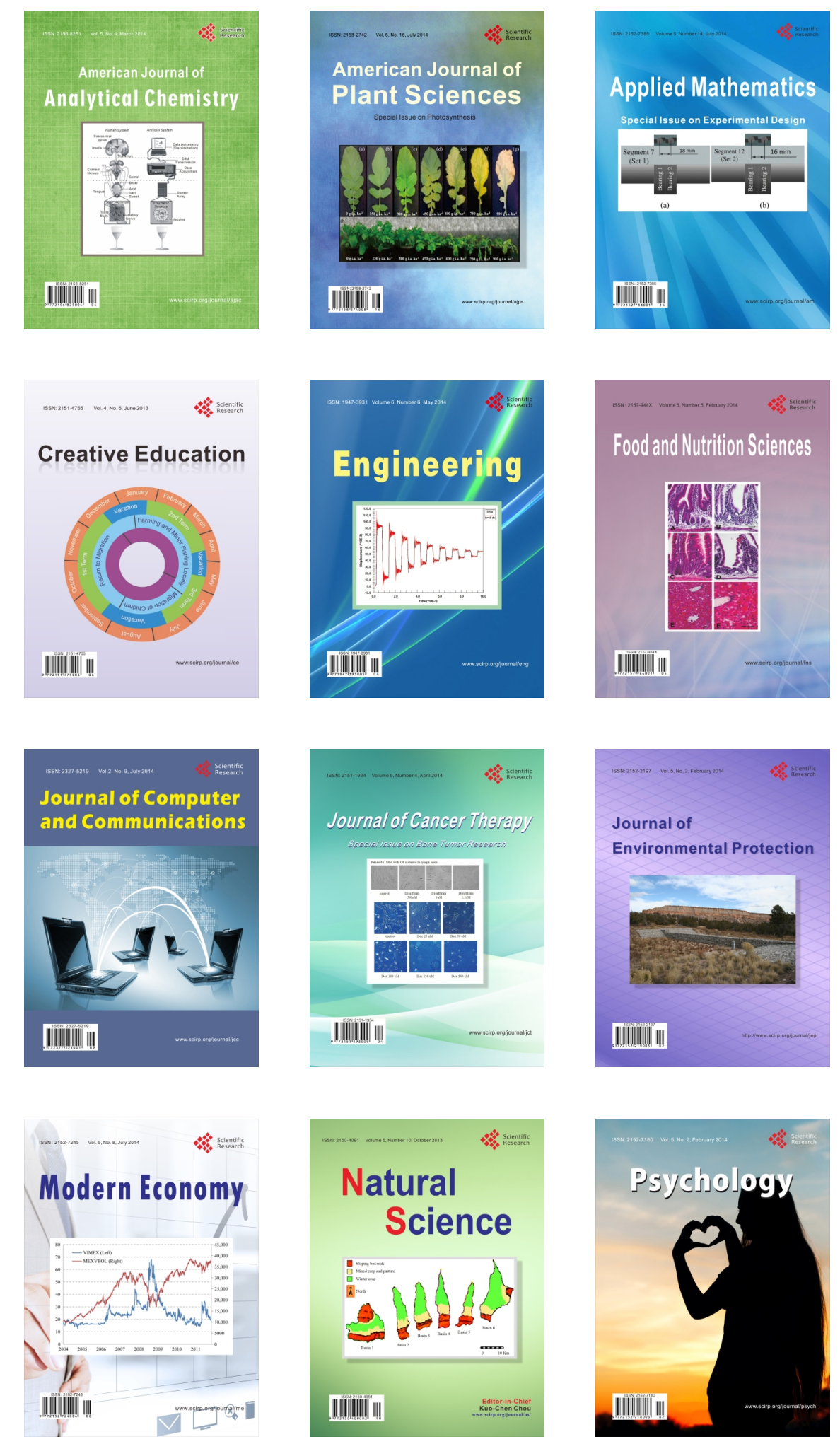